\title{
Pengaruh Ramipril Terhadap Gambaran Histopatologis Otak Tikus Wistar yang Mengalami Edema Otak
}

\author{
Rizka Fitria Husni ${ }^{1}$, Nita Afriani ${ }^{2}$, Aswiyanti Asri ${ }^{3}$ \\ ${ }^{1}$ S1 Kedokteran, Fakultas Kedokteran Universitas Andalas, Limau Manis, Padang, 25163, Indonesia \\ ${ }^{2}$ Bagian Histologi, Fakultas Kedokteran Universitas Andalas, Limau Manis, Padang, 25163, Indonesia \\ ${ }^{3}$ Bagian Patologi Anatomi, Fakultas Kedokteran Universitas Andalas, Limau Manis, Padang, 25163, Indonesia
}

\author{
A B S T R A C T
}

\begin{abstract}
Latar Belakang. Edema otak adalah akumulasi cairan yang berlebihan pada ruang intrakranial dan atau ekstraseluler dari otak. Edema otak dapat disebabkan oleh trauma kepala, tumor otak, hipoksia, gangguan metabolisme, atau hipertensi akut. Infark miokard akut adalah kerusakan otot jantung yang terjadi akibat kekurangan oksigen. Pada saat jantung mengalami infark miokard akut, akan terjadi gangguan aliran darah berupa stasis yang memungkinkan terjadinya emboli dan penurunan CO (Cardiac Output) yang akan menyebabkan penurunan pada CBF (Cerebral Blood Flow). Pada keadaan ini, akan terjadi keadaan iskemia dan hipoksia sehingga mekanisme hemostatik terganggu yang akan memicu terjadinya edema otak.
\end{abstract}

Objektif. Penelitian ini dilakukan untuk melihat pengaruh pemberian ramipril terhadap gambaran histopatologis otak tikus wistar yang mengalami edema otak.

Metode. Penelitian ini merupakan penelitian eksperimental dengan rancangan the post test only control group design. Penelitian ini menggunakan 32 ekor hewan coba yang dibagi dalam 4 kelompok (K-, $\mathrm{K}+, \mathrm{P}_{1}$, dan $\mathrm{P}_{2}$ ). Kelompok perlakuan 1 diberikan profilaksis ramipril $3 \mathrm{mg} / \mathrm{kgBB}$ selama 7 hari berturut-turut. Kelompok perlakuan 2 diberikan profilaksis ramipril $4 \mathrm{mg} / \mathrm{kgBB}$ selama 7 hari berturut-turut. Pada Hari ke 8 dan 9, kelompok perlakuan dan kontrol positif diinduksi isoproterenol $85 \mathrm{mg} / \mathrm{kgBB}$ selama 2 hari berturut untuk menginduksi edema otak melalui mekanisme infark miokard akut. Analisis data menggunakan uji One Way Anova dan Post Hoc Bonferroni.

Hasil. Rerata luas edema otak pada kelompok K-, $\mathrm{K}+, \mathrm{P}_{1}$, dan $\mathrm{P}_{2}$ berturut-turut adalah 20,76\%, 34,69\%, 22,70\%, dan 21,90\%.

Kesimpulan. Adanya pengaruh pemberian ramipril yang bermakna terhadap gambaran histopatologis otak tikus wistar yang mengalami edema otak.

Kata kunci: Edema otak, infark miokard akut, isoproterenol, Ramipril
Background. Brain edema is excessive accumulation of fluid in the intracranial or extracellular space of the brain. It can be caused by head trauma, brain tumors, hypoxia, metabolic disorders, or acute hypertension. Acute myocardial infraction is damage to the myocard that occurs due to lack oxygen. When acute myocardial infarction occurs, there will be disruption of blood flow in the form of stasis which allows emboli and decreased Cardiac Output which will cause a decrease in Cerebral Blood Flow. There will be a state of ischemia and hypoxia so that the hemostatic mechanism is disturbed which will trigger brain edema.

Objective. This research was conducted to see the effect of giving ramipril to histopathological of the brain of wistar rat with brain edema.

Methods. This research is an experimental study. We used 32 animals which were divided into 4 groups $(K-, K+, P 1$, and $P 2)$. $P_{1}$ was given $3 \mathrm{mg} / \mathrm{kgBW}$ ramipril for 7 consecutive days. $P_{2}$ was given $4 \mathrm{mg} / \mathrm{kgBW}$ ramipril for 7 consecutive days. On days 8 and $9, P_{1}, P_{2}$, and $K+$ induced isoproterenol 85 $\mathrm{mg} / \mathrm{kgBW}$ for 2 consecutive days to induce brain edema through the mechanism of acute myocardial infarction. Data analysis was performed using One Way Anova test and Post Hoc Bonferroni test.

Results. The mean area of brain edema in the $K-, K+, P 1$, and $P 2$ groups respectively were $20.76 \%, 34.69 \%, 22.70 \%$, and $21.90 \%$.

Conclusion. There was a significant effect of giving ramipril to histopathological of the brain of wistar rat with brain edema.

Keyword: Brain edema, acute myocardial infarction, isoproterenol, ramipril 
Apa yang sudah diketahui tentang topik ini?

Ramipril merupakan ACE-I (Angiotensin Converting Enzyme-Inhibitor) yang dapat mencegah peningkatan kerusakan miokard pada tikus yang mengalami IMA (Infark Miokard Akut). Kerusakan miokard pada IMA dapat menurunkan CO (Cardiac Output) dan menyebabkan keadaan hipoksik iskemik pada otak.
Apa yang ditambahkan pada studi ini?

Terdapat perbedaan yang bermakna antara luas edema otak pada tikus yang mengalami infark miokard akut tanpa profilaksis ramipril dengan yang diberikan profilaksis ramipril

\section{CORRESPONDING AUTHOR}

Phone: +62 81378957621

E-mail: rizkafitriahusni06@gmail.com

ARTICLE INFORMATION

Received: November $12^{\text {th }}, 2020$

Revised: July $17^{\text {th }}, 2021$

Available online: July $30^{\text {th }}, 2021$

menyebabkan perfusi ke berbagai organ termasuk otak tidak adekuat. ${ }^{6}$

Jantung yang mengalami infark miokard akut akan mengalami non-kontraktilitas pada miokard setempat dan aliran darah menjadi abnormal berupa stasis yang mempermudah terbentuknya trombosis. Trombosis yang terbentuk dapat berpotensi menjadi emboli sistemik (80\%). Duapertiga dari keseluruhannya berhubungan dengan infark pada ventrikel kiri. Emboli arteri dapat masuk kemana saja, 75\% pada ekstremitas dan $10 \%$ pada sistem saraf pusat. Emboli merupakan penyebab tersering terjadinya iskemia dan stroke. ${ }^{7}$

Penurunan pasokan darah ke otak dapat menyebabkan keadaan hipoksia dan iskemia akut pada otak akibat tidak adekuatnya suplai nutrisi dan oksigen. Keadaan hipoksia dan iskemia serebral mengakibatkan terganggunya mekanisme hemostatik berupa deplesi ATP (Adenosine Triphosphate) pada intraseluler sehingga terjadi disfungsi pada pompa Na-K. Keadaan ini dapat menyebabkan edema otak jenis sitotoksik hanya dalam hitungan menit. ${ }^{2}$

Edema serebral atau pembengkakan pada otak yang terjadi dapat menyebabkan tekanan intrakranial meningkat bahkan hipertensi intrakranial. Hal ini sesuai dengan hukum Monroe-Kellie, bahwa tekanan intrakranial dipengaruhi oleh 3 komponen, yaitu: jaringan otak, darah, dan cairan serebrospinal yang masing-masing telah memiliki proporsi tetap. Peningkatan salah satu komponen akan menyebabkan gangguan pada komponen lainnya dan menyebabkan peningkatan tekanan intrakranial. Akibatnya, sel neuron dan kapiler akan tertekan sehingga menyebabkan perkembangan lesi dan kerusakan saraf.. ${ }^{1}$ 
Pemberian ACE-I (Angiotensin Converting Enzyme-Inhibitors) adalah terapi medikamentosa yang paling tepat dalam keadaan infark miokard akut. ACE-I merupakan vasodilator yang bekerja dengan cara menurunkan tahanan perifer sehingga dapat menurunkan tekanan darah. ${ }^{8} \mathrm{Hal}$ ini dapat mengatasi infark miokard akut secara efektif. Namun, berbeda dengan edema otak. Terapi pilihan untuk edema otak adalah osmoterapi dimana pemberian diuretik seperti mannitol paling populer digunakan. Osmoterapi ini akan bekerja dengan cara mengubah viskositas darah sehingga dapat menurunkan tekanan intrakranial. ${ }^{9}$

Berdasarkan penelitian terdahulu yang telah dilakukan Bayir dkk (2009) bahwa pemberian awal ACE-I ramipril dengan dosis $3 \mathrm{mg} / \mathrm{kgBB}$ mempunyai efek profilaksis terhadap infark miokard akut. Hal ini dijelaskan dengan pencegahan kenaikan BNP (Brain Natriuretic Peptide) yang merupakan marker kerusakan jantung. Pada penelitian terdahulu, belum ditemukan adanya penelitian yang mengkaji hubungan kejadian infark miokard akut dengan edema otak serta efek profilaksis tidak langsung ramipril pada edema otak. Hal ini penting karena kerusakan otak yang terjadi akibat dari edema otak dapat berakibat fatal hingga kematian.

Penelitian ini dilakukan untuk mengetahui gambaran histopatologis otak tikus wistar yang mengalami edema otak, pengaruh profilaksis ramipril dosis $3 \mathrm{mg} / \mathrm{kgBB}$ dan $4 \mathrm{mg} / \mathrm{kgBB}$ terhadap gambaran histopatologis tersebut, serta perbedaan gambaran histopatologis dari masingmasing kelompok hewan penelitian.

\section{Metode}

Penelitian ini merupakan penelitian eksperimental dengan rancangan the post test only control group design. Sampel penelitian dihitung menggunakan rumus Federer: $(\mathrm{t}-1)(\mathrm{n}-1)$, penelitian ini membutuhkan 32 ekor tikus galur wistar jantan yang dibagi dalam 4 kelompok penelitian. Populasi sampel adalah tikus galur wistar jantan sehat yang berumur 6-8 minggu saat pemilihan sampel dengan berat badan tikus 150180 gram dan tidak memiliki cacat anatomi. Penelitian dilakukan setelah lolos uji etik Fakultas Kedokteran Universitas Andalas dengan No. 343/KEP/FK/2020.
Dilakukan penelitian pendahuluan pada tikus dengan kriteria yang sama untuk melihat kejadian infark miokard akut pada tikus dengan induksi isoproterenol $85 \mathrm{mg} / \mathrm{kgBB}$ selama 2 hari berturutturut. (Gambar 1) Terlihat adanya edema miokard yang merupakan penanda dan tahap awal dari infark miokard akut.

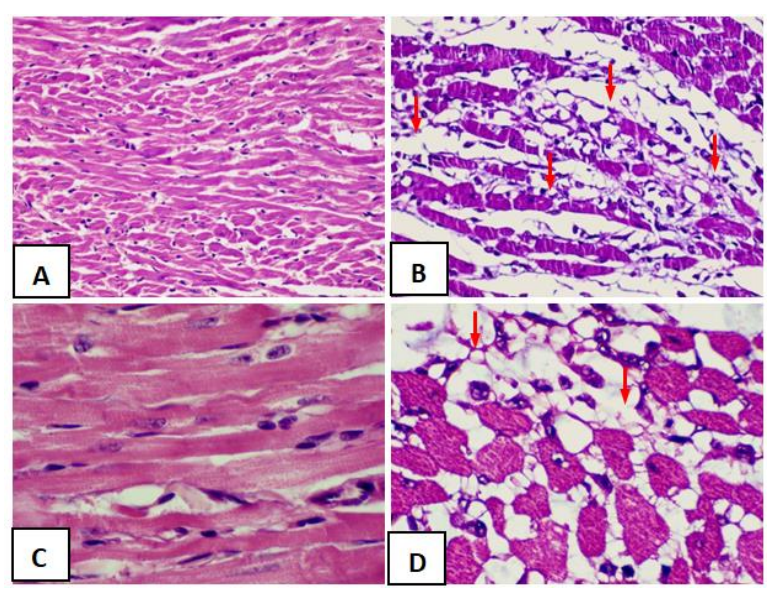

Gambar 1. Gambaran histologis miokard tikus (A) Kelompok kontrol (-) perbesaran objektif 40x, (B) Kelompok kontrol (+) yang hanya diinduksi isoproterenol $85 \mathrm{mg} / \mathrm{kgBB}$ dengan perbesaran objektif 40x, (C)

Kelompok kontrol (-) perbesaran objektif 100x, (D)

Kelompok kontrol (+) yang hanya diinduksi isoproterenol $85 \mathrm{mg} / \mathrm{kgBB}$ dengan perbesaran objektif 100x.

Penelitian luas edema otak pada tikus dilakukan dengan aklimatisasi selama 7 hari dengan diet standar dengan pengelolaan laboratorium dan dipaparkan dalam siklus terang selama 12 jam dan siklus gelap selama 12 jam. Apabila tikus mati atau mengalami penurunan berat badan $>10 \%$ dan tampak sakit, maka tikus akan diganti dengan tikus dengan kriteria yang sama secara acak .

Tikus dibagi menjadi 4 kelompok yaitu kelompok kontrol (-), kontrol (+), perlakuan 1, dan perlakuan 2. Kelompok kontrol (-) hanya diberikan diet standar. Pada hari 1-7, kelompok perlakuan 1 dan perlakuan 2 diberikan profilaksis ramipril masing-masing $3 \mathrm{mg} / \mathrm{kgBB}$ dan 4 $\mathrm{mg} / \mathrm{kgBB}$. Pada hari ke 8-9, kelompok kontrol (+), perlakuan 1, dan perlakuan 2 diinduksi dengan isoproterenol $85 \mathrm{mg} / \mathrm{kgBB}$. Dilakukan terminasi pada hari ke-10 dan pengambilan organ otak hewan coba untuk dibuatkan preparat dengan pewarnaan Haematoxylin Eosin.

Preparat akan dibaca menggunakan mikroskop Olympus BX31 dengan perbesaran 400x dan diambil gambar sebanyak tiga lapangan pandang 
yang paling representatif terhadap edema otak, yaitu adanya pembengkakan sel astrosit, dilatasi pembuluh darah, atau matriks yang sembab, dan dihitung berapa luas edema otaknya dengan aplikasi ImageJ 2018 versi 1.52a. Luas edema otak yang didapatkan akan dimasukkan ke tabel distribusi frekuensi. Data tersebut akan dianalisis menggunakan One Way Anova dan Post Hoc Bonferroni. Apabila data tidak terdistribusi normal maka dilakukan uji alternative Kruskal Wallis.

\section{Hasil}

Gambaran histologis dari masing-masing kelompok hewan coba didapatkan dengan menggunakan mikroskop Olympus BX31 dengan perbesaran 400x (Gambar 2). Terlihat adanya gambaran edema otak yang ditandai oleh matriks yang sembab, pembengkakan sel astrosit, serta dilatasi pembuluh darah.
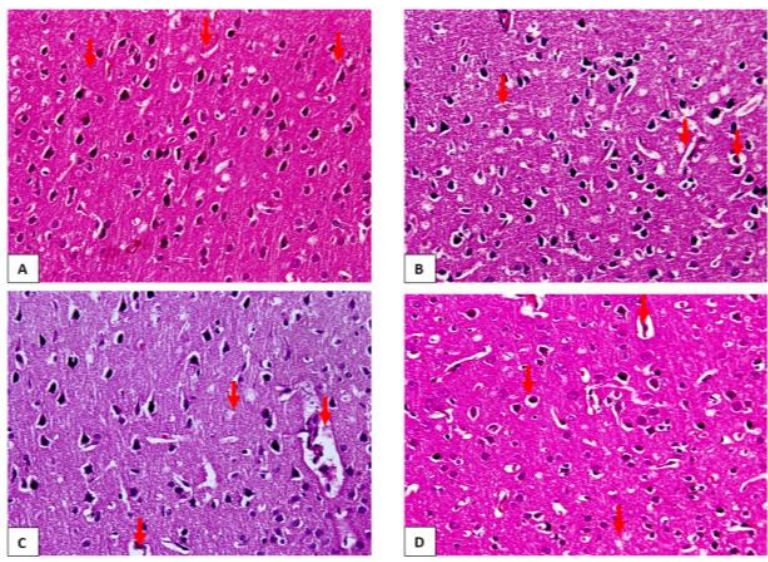

Gambar 2. Gambaran histologis dari masing-masing kelompok hewan coba. Haematoxylin Eosin. Perbesaran 400x. (A) Kelompok kontrol (-), (B) Kelompok kontrol (+) yang hanya diinduksi isoproterenol $85 \mathrm{mg} / \mathrm{kgBB},(\mathrm{C})$ Kelompok perlakuan 1 dengan profilaksis ramipril 3 $\mathrm{mg} / \mathrm{kgBB}$ dan diinduksi isoproterenol $85 \mathrm{mg} / \mathrm{kgBB}$, dan (D) Kelompok perlakuan 2 dengan profilaksis ramipril 4 $\mathrm{mg} / \mathrm{kgBB}$ dan diinduksi isoproterenol $85 \mathrm{mg} / \mathrm{kgBB}$.

Kemudian dihitung luas edema dengan menggunakan aplikasi ImageJ 1.52a. (Gambar 3). Daerah yang berwarna hitam merupakan luas edema otak yang dihitung. Didapatkan data rerata luas edema pada tiap kelompok hewan coba (Tabel 1).
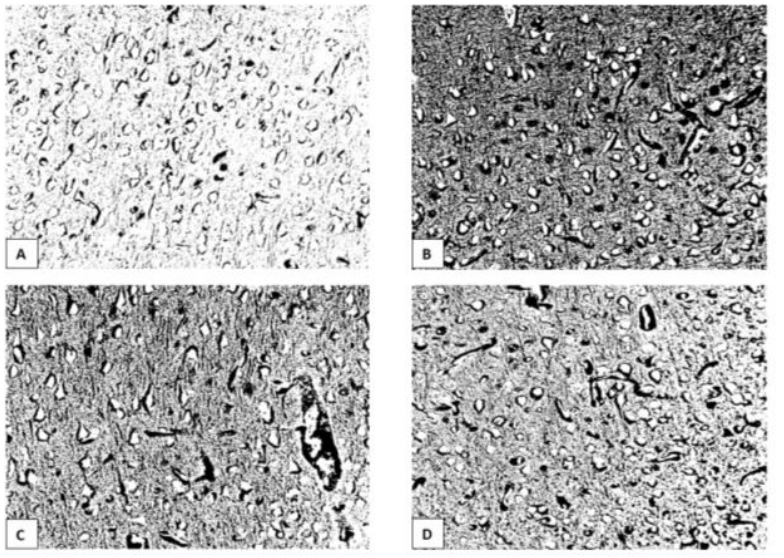

Gambar 3. Gambaran histologis dari masing-masing kelompok hewan coba dengan aplikasi ImageJ 2018 versi 1.52a. (A) Kelompok kontrol (-), (B) Kelompok kontrol (+) yang hanya diinduksi isoproterenol $85 \mathrm{mg} / \mathrm{kgBB},(\mathrm{C})$ Kelompok perlakuan 1 dengan profilaksis ramipril 3 $\mathrm{mg} / \mathrm{kgBB}$ dan diinduksi isoproterenol $85 \mathrm{mg} / \mathrm{kgBB}$, dan

(D) Kelompok perlakuan 2 dengan profilaksis ramipril 4 $\mathrm{mg} / \mathrm{kgBB}$ dan diinduksi isoproterenol $85 \mathrm{mg} / \mathrm{kgBB}$.

Tabel 1. Rerata Luas Edema Otak

\begin{tabular}{ll}
\hline Kelompok & Rerata Luas Edema (\%) \pm SD \\
\hline Kontrol Negatif & $20,76 \pm 1,48$ \\
Kontrol Positif & $34,69 \pm 2,23$ \\
Perlakuan 1 & $22,70 \pm 1,97$ \\
Perlakuan 2 & $21,90 \pm 0,70$ \\
\hline
\end{tabular}

Data tersebut dianalisis dengan One Way Anova, didapatkan $\mathrm{p}=0,000$, yaitu semua kelompok penelitian menunjukkan perbedaan luas edema yang bermakna. Perbedaan signifikasi masing-masing kelompok didapatkan dari uji Post Hoc Bonferroni, terdapat perbedaan signifikan pada luas edema pada kelompok kontrol $(+)$ dengan kontrol $(-)$, kelompok kontrol $(+)$ dengan perlakuan 1, dan kelompok kontrol $(+)$ dengan perlakuan 2 (Tabel 2).

Tabel 2. Perbedaan Signifikan Kelompok Penelitian

\begin{tabular}{lll}
\hline Kelompok Penelitian & & $\mathrm{P}$ \\
\hline Kontrol - & Kontrol + & $0,000^{*}$ \\
& Perlakuan 1 & $0,261^{*}$ \\
& Perlakuan 2 & $1,000^{*}$ \\
Kontrol + & Kontrol - & $0,000^{*}$ \\
& Perlakuan 1 & $0,000^{*}$ \\
& Perlakuan 2 & $0,000^{*}$ \\
Perlakuan 1 & Kontrol - & $0,261^{*}$ \\
& Kontrol + & $0,000^{*}$ \\
& Perlakuan 2 & $1,000^{*}$
\end{tabular}




\begin{tabular}{ccc}
\multicolumn{2}{c}{ Kelompok Peneltian } & P \\
\hline Perlakuan 2 & Kontrol - & $1,000^{*}$ \\
& Kontrol + & $0,000^{*}$ \\
& Perlakuan 1 & $1,000^{*}$ \\
\hline
\end{tabular}

Keterangan : Dilakukan dengan uji Post Hoc Bonferroni

*Perbedaan signifikan $(\mathrm{p}<0,05)$

\section{Pembahasan}

Hasil penelitian ini menunjukkan terjadinya kerusakan otak pada tikus kelompok kontrol positif yang diinduksi isoproterenol. Gambaran histologis otak didapatkan adanya kerusakan berupa edema otak yang ditandai dengan pembengkakan sel astrosit, dilatasi pembuluh darah, atau matriks yang sembab. ${ }^{10}$

Kerusakan yang terjadi disebabkan induksi dari isoproterenol. Isoproterenol adalah agonis reseptor beta adrenergik yang dapat menyebabkan peningkatan denyut dan kontraktilitas jantung. ${ }^{11,12}$ Isoproterenol dapat menyebabkan perubahan permeabilitas pada mitokondria, peningkatan uptake kalsium, dan radikal bebas. Hal ini akan menyebabkan kerusakan lipid, protein, dan DNA pada otot jantung yang mengindikasikan proses apoptosis dan nekrosis pada otot jantung tersebut. Pemberian isoproterenol dengan dosis yang adekuat secara subkutan pada hewan coba dapat menginduksi infark miokard akut. ${ }^{13}$

Penelitian ini sejalan dengan penelitian yang dilakukan Widyaningsih dkk pada tahun 2015 yang menggunakan isoproterenol selama dua hari berturut-turut secara subkutan dengan dosis 85 $\mathrm{mg} / \mathrm{kgBB}$ sebagai penginduksi infark miokard akut yang dibuktikan dengan perubahan pada EKG jantung tikus. ${ }^{14}$

Pemberian ramipril sebelum terjadinya infark miokard akut pada tikus dapat mengurangi kerusakan otak akibat infark miokard akut yang diinduksi isoproterenol. Terlihat ukuran luas edema otak yang berkurang pada tikus kelompok perlakuan 1 dan perlakuan 2. Hal ini menunjukkan bahwa pemberian profilaksis ramipril mampu mengurangi iskemia sedemikian rupa sehingga kerusakan otak tidak terlalu parah. Ramipril merupakan ACE-I yang bekerja dengan cara menghambat enzim pengonversi angiotensin dan menurunkan pembentukan angiotensin II. ${ }^{16}$ Hal ini dapat mencegah kenaikan tekanan darah. Pencegahan dengan ramipril bertujuan untuk menstabilkan tekanan darah serta mengurangi mortalitas pada keadaan infark miokard akut. ${ }^{17}$

Berdasarkan data yang diperoleh dari hasil penelitian ini didapatkan adanya perbedaan gambaran histologis otak pada tiap-tiap kelompok penelitian. Untuk mengetahui apakah perbedaan itu bermakna atau tidak, dilakukan analisis statistik dengan uji parametrik One Way ANOVA. Hasil uji didapatkan nilai $\mathrm{p}=0,000(\mathrm{p}<0,00)$ artinya terdapat perbedaan gambaran histologis otak yang bermakna pada tiap-tiap kelompok penelitian. Untuk mengetahui perbedaan signifikan pada masing-masing kelompok, dilakukan analisis lebih lanjut dengan menggunakan uji Post Hoc Bonferroni.

Pada uji Post Hoc Bonferroni didapatkan pada kelompok kontrol negatif dan kelompok kontrol positif, nilai $p=0,00(p<0,05)$ artinya terdapat perbedaan yang signifikan antara kelompok kontrol negatif dengan kelompok kontrol positif. Perbedaan yang signifikan tersebut terlihat dari peningkatan rerata luas edema otak. Kelompok kontrol negatif yang pada penelitian ini sebagai kontrol penelitian memiliki rerata luas edema otak sebesar $20,76 \%$. Pada kontrol positif rerata luas edema otak meningkat menjadi 34,69\%. Hasil uji analisis pada kelompok kontrol positif dengan kelompok perlakuan 1 didapatkan nilai $p=0,000$ $(\mathrm{p}<0,05)$ yaitu terdapat perbedaan gambaran histologis otak yang signifikan. Hasil uji analisis antara kelompok kontrol positif dengan kelompok perlakuan 2 didapatkan nilai $\mathrm{p}=0,000(\mathrm{p}>0,05)$ yaitu juga terdapat perbedaan gambaran histologis otak yang signifikan.

Hasil pada penelitian ini menunjukkan bahwa dengan pemberian profilaksis ramipril dengan dosis $3 \mathrm{mg} / \mathrm{kgBB}$ dan $4 \mathrm{mg} / \mathrm{kgBB}$ dapat mengurangi kerusakan pada otak.

\section{Simpulan}

Gambaran histopatologis otak tikus wistar (Rattus norvegicus) yang mengalami edema otak terlihat adanya kerusakan otak berupa pembengkakan sel astrosit, dilatasi pembuluh darah, serta matriks yang sembab. Pemberian profilaksis ramipril pada kelompok perlakuan 1 dan perlakuan 2 dengan dosis $3 \mathrm{mg} / \mathrm{kgBB}$ dan 4 $\mathrm{mg} / \mathrm{kgBB}$ sebelum diinduksi dengan isoproterenol mengalami perbaikan pada gambaran histopatologis berupa luas edema otak yang semakin mengecil. Terdapat perbedaan yang 
bermakna antara kelompok tikus yang dijadikan infark miokard akut melalui induksi isoproterenol tanpa profilaksis ramipril dengan yang diberikan profilaksis ramipril. Terjadi penurunan luas edema dengan ramipril dosis $4 \mathrm{mg} / \mathrm{kgBB}$ dibandingkan dengan ramipril dosis $3 \mathrm{mg} / \mathrm{kgBB}$.

\section{Ucapan Terima Kasih}

Kepada dr. Gestina Aliska, Sp.FK, dr. Tofrizal, M.Biomed, Sp.PA., Ph.D, dan dr. Alief Dhuha, Ph.D yang telah membantu dalam penelitian ini.

\section{Daftar Pustaka}

1. Stokum JA, Gerzanich V, Simard JM. Molecular pathophysiology of cerebral edema. J Cereb Blood Flow Metab. 2016;36(3):513-538. doi:10.1177/0271678X15617172

2. Michinaga S, Koyama Y. Pathogenesis of brain edema and investigation into anti-edema drugs. Int $J \quad$ Mol Sci. 2015;16(5):9949-9975. doi:10.3390/ijms16059949

3. Shamsaei, Nabi.; Erfani, Soheila.; Fereidoni, Masoud.; Shahbazi A. Neuroprotective Effects of Exercise on Brain Edema and Neurological Movement Disorders Following the Cerebral Ischemia and Reperfusion in Rats. Basic Clin Neurosci. Published online 2017:77-84.

4. Dostovic, Zikrija; Dostovic E. Brain Edema After Ischaemic Stroke. Med Arch.:70(5): 339-341. doi:10.5455/medarh.2016.70.339-341

5. Grossman OJMSA. Acute Myocardial Infarction. In: ;2019.

6. Wilder J, Sabatine MS, Lilly LS. Sindroma Koroner Akut. In : Lilly LS. Patofisiologi penyakit jantung : kolaborasi mahasiswa dan dosen; alih bahasa Denio A. Ridjab; editor edisi Bahasa Indonesia, Dafsah A. Juzar. Edisi 6. Jakarta: Penerbit Buku Kedokteran.

7. Kamel H. Cardioembolic Stroke.Circulation Research.2017;120:514-526. doi:10.1161/CIRCRESAHA.116.308407

8. Shah, Ami; Gandhi D. Heart Failure: A Class Review of Pharmacotherapy. PharmD.:42(7): 464472.

9. Mesghali E, Fitter S, Bahjri K, Moussavi K. Safety of Peripheral Line Administration of 3\% Hypertonic Saline and Mannitol in the Emergency Department. J Emerg Med. 2019 Apr;56(4):431436.

10. Rahaman P, Del Bigio MR. Histology of Brain Trauma and Hypoxia-Ischemia. Acad Forensic Pathol. doi:10.1177/1925362118797728

11. Massberg S, Polzin A. [Update ESC-Guideline 2017: Dual Antiplatelet Therapy]. Dtsch. Med. Wochenschr. 2018 Aug; 143 (15):1090-1093.

12. Nascimento BR, Brant LCC, Marino BCA, Passaglia LG, Ribeiro ALP. Implementing myocardial infarction systems of care in low/middle-income countries. Heart. 2019 Jan; 105 (1):20-26.

13. Neulinger K, Oram J, Tinson H, O'Gorman J, Shum DH. Prospective memory and frontal lobe function. Neuropsychol Dev Cogn B Aging Neuropsychol Cogn. 2016; 23 (2):171-83.
14. Berlucchi G, Vallar G. The history of the neurophysiology and neurology of the parietal lobe. Handb Clin Neurol. 2018; 151 :3-30.

15. Clark RE. Current Topics Regarding the Function of the Medial Temporal Lobe Memory System. Curr Top Behav Neurosci. 2018; 37 :13-42.

16. Huff T, Mahabadi N, Tadi P. StatPearls [Internet]. StatPearls Publishing; Treasure Island (FL): Oct 5, 2019. Neuroanatomy, Visual Cortex.

17. Chandra A. The cerebral circulation and cerebrovascular disease I: Anatomy. Brain Circ . 2017 Apr-Jun; 3(2): 45-56. doi:10.4103/bc.bc_10_17 